\title{
A Note on the Taxation of Couples Under Income Uncertainty
}

Giacomo Corneo

School of Business \& Economics

Discussion Paper

Economics

$2011 / 16$ 


\title{
A Note on the Taxation of Couples Under Income Uncertainty
}

\author{
Giacomo Corneo* \\ August 2011
}

\begin{abstract}
An unduly neglected implication of the choice of the tax unit is its impact on the consumption risk carried by taxpayers. As compared to individual taxation, joint taxation with income splitting provides couples with more insurance against the risk of earning inability for one of the spouses. If that risk is not insurable in markets, replacing individual taxation with joint taxation with income splitting can generate a Pareto-improvement.

$J E L: \mathrm{H} 2$
\end{abstract}

Keywords: progressive income tax, tax unit, insurance.

*Free University of Berlin, CEPR, London, CESifo, Munich, and IZA, Bonn. Corresponding author's address: Professor G. Corneo, Department of Economics, Free University of Berlin, Boltzmannstr. 20, 14195 Berlin, Germany; e-mail: giacomo.corneo@fu-berlin.de. 


\section{Introduction}

In contrast to single persons, individuals living as a married couple have entered a longterm comittment to share their resources and support each other. While that commitment strongly affects social policy legislation, its recognition in income taxation varies across countries. As a matter of fact, the majority of OECD countries taxes couples on an individual basis, i.e. husband's income and wife's income are separately taxed according to the same tax schedule that is used for single persons. Only a few countries apply some form of joint taxation where a couple's tax liability depends on its total income. How couples should be taxed is a long-standing issue in public economics, and one with many aspects. The literature has investigated a number of equity and incentive aspects of the problem. Early papers such as Fraser (1986) pointed out the impossibility of having a tax system that is directly progressive, has couples with equal income paying equal taxes, and where no marriage tax or subsidy exists. More recent papers, including Piggott and Whalley (1996), Gottfried and Richter (1999), Schroyen (2003), Kleven and Kreiner (2007), Cremer et al. (2007), and Kleven et al. (2009), have analyzed the taxation of couples' incomes in an optimal taxation framework with endogenous labor supply and home production. A recent overview of the state of the art is offered by Apps and Rees (2009).

The aim of this note is to put forward consumption risk as an ingredient that should affect the choice of the tax unit. While the insurance effect from a progressive income tax has been well known since at least the seminal papers by Eaton and Rosen (1980) and Varian (1980), the literature on the tax treatment of couples is limited to the analysis of deterministic settings. That literature thus neglects the implications of different systems of household taxation for the consumption risk carried by households. This notes provides a first step in that dierction by comparing individual taxation and joint taxation with income splitting in a simple model where individuals are subject to a non-insurable earning risk. It is shown that joint taxation with income splitting is superior in the Pareto sense: given some arbitrary progressive tax schedule, a move from a system of individual taxation to one of joint taxation with income splitting makes all couples better off ex ante. The intuition for this result is that joint taxation with income splitting increases the amount of insurance implicitly offered by the government: as compared to individual taxation, joint taxation with income splitting eliminates more consumption risk because it generates a "splitting gain" in case of bad luck for one of the spouses.

Casual observation suggests that the insurance effect at work in the current model may be highly relevant in practice. Inability to find a job, failure of own business, necessity to look after a disabled family member, own physical disability, chronic illness, depression 
and other mental disorders are frequent sources of substantial earning risk that cannot be efficiently insured in markets. While for single persons the risk of insufficient market income is usually covered by the transfer system, two married persons carry much of that risk by themselves, as they only receive welfare payments if the sum of their individual market incomes is deemed insufficient. For a normative assessment of the tax treatment of couples it is therefore important to understand how the various systems help households to reduce their consumption risk. ${ }^{1}$

\section{$2 \quad$ Model}

\subsection{Assumptions}

Consider a total population with mass $2+\sigma$ consisting of two identical continua of men and women, where $\sigma \geq 0$. Both men and women are characterized by their type $y$ which represents an individual's earnings potential. There is a finite number of types; the lowest type is denoted by $\underline{y}>0$, the highest by $\bar{y} \geq \underline{y}$, and the fraction of type- $y$ individuals in the population is $\mu_{y}$, where $\Sigma_{y} \mu_{y}=1$. Ex post, each individual may be either in the good state, where the individual realizes its earning potential and receives a market income equal to its type, or in the bad state, where no market income is received. Individual risks are identically and independently distributed and the probability of the bad state for an individual is denoted by $\pi \in(0,1)$.

Individuals are either singles or married persons. The mass of singles is $\sigma$, so that the remaining individuals form a continuum of unit mass of couples. The fraction of individuals who stay single is the same for all types and couples consist of a man and a woman of the same type. This can be interpreted as the stable configuration of a process of voluntary matching among all individuals who want to get married. In case of marriage, spouses pool their incomes within the couple and jointly consume their total disposable income. A couple's von Neumann-Morgenstern utility function is denoted by $U(c)$, where $c$ is the couple's total disposable income and $U^{\prime}>0>U^{\prime \prime}$.

The government raises money by means of a progressive income tax in order to finance transfers to households without market income and to cover administrative costs. The income tax schedule $T(y)$ satisfies $T(0)=0,0<T^{\prime}<1$ and $T^{\prime \prime}>0$. Two systems of

\footnotetext{
${ }^{1}$ According to OECD (2009), only $86 \%$ of men in age between 25 and 54 were in employment (including part-time) in 2008 in the US. The corresponding number for women is $72.3 \%$. Numbers for the EU-19 countries are similar. If one assumes that all men in that age group would in principle like to work, the $14 \%$ out of employment give an idea about the magnitude of the earning risk modelled in this note. If one somewhat heroically assumes that women face the same earning risk as men, the above numbers suggest that less than half of female unemployment is voluntary.
} 
taxation of couples are considered: individual taxation and joint taxation with income splitting. In case of individual taxation, each spouse's income is separately taxed. In case of joint taxation, the spouses' incomes are added together and taxed as if they had each earned one half of their total income. The two tax systems are compared in terms of expected utility when the government has to raise the same tax revenue under both systems. Any difference in the tax revenue generated by $T(\cdot)$ between the two systems is assumed to be covered by an additional tax or subsidy such that the final amount of tax collected from each type is the same under both systems.

\subsection{Budget constraint of government}

Because of the law of large numbers, the fraction of singles with zero market income is given by $\pi$ and the fraction of couples with zero market income is given by $\pi^{2}$. Hence, total public expenditures is given by $R \equiv G+\pi \sigma z_{s}+\pi^{2} z_{m}$, where $G$ denotes administration costs, $z_{s}$ is the transfer to singles with zero earnings, and $z_{m}$ is the transfer to couples without earnings. Let $R_{y}$ denote the tax revenue collected from type $y$. The tax schedule is such that the government meets its budget constraint, i.e. $\Sigma_{y} R_{y}=R$.

Under joint taxation with income splitting, the tax paid by type $y$ is given by

$$
R_{y}=\mu_{y}\left[(1-\pi) \sigma T(y)+2 \pi(1-\pi) 2 T(y / 2)+(1-\pi)^{2} 2 T(y)\right] .
$$

The first term in the square bracket on the r.h.s. represents the tax revenue from single earners, the second term is tax revenue from couples where only one spouse receives an income, and the third term refers to two-earners couples.

In case of individual taxation, the tax revenue only depends on the number of individuals with market income, independently of their marriage status. The tax collected from type $y$ amounts to

$$
R_{y}=\mu_{y}(1-\pi)(2+\sigma)[T(y)-s(y)]
$$

where $s(y)$ is the differential taxation which is necessary to equalize the tax revenue under the two systems of taxation. Combining (1) and (2) yields

$$
s(y)=\frac{2 \pi}{2+\sigma} V(y)
$$

where $V(y)=T(y)-2 T(y / 2)$ is the splitting gain under joint taxation for one-earner couples. Because of progressivity, $V(y)>0$ which implies $s(y)>0$, i.e. the tax schedule is higher under joint taxation than under individual taxation. Notice that also the adjusted tax schedule for individual taxation, $T(y)-s(y)$, satisfies $T(0)-s(0)=0,0<T^{\prime}-s^{\prime}<1$ and $T^{\prime \prime}+s^{\prime \prime}>0$. 


\subsection{Welfare comparison}

Each couple of a given type can find itself in three different states. With probability $(1-\pi)^{2}$ the couple is in state 1 where both spouses earn market income and jointly consume disposable income $c_{1}(y)$. With probability $2 \pi(1-\pi)$ the couple is in state 2 where only one of the two spouses can earn income and they jointly consume $c_{2}(y)$. With probability $\pi^{2}$ both spouses earn nothing and jointly receive the welfare benefit for couples $z_{m}$, which determines their consumption level in the third state. Assume that $z_{m}<c_{i}(\underline{y})$, $i \in\{1,2\}$ and normalize the utility function of couples so that $U\left(z_{m}\right)=0$. Short of a positive multiplicative factor, a couple's expected utility can be expressed as

$$
E[U]=(1-\pi) U\left(c_{1}(y)\right)+2 \pi U\left(c_{2}(y)\right) .
$$

The following fact can be established:

Proposition 1. For all types, the expected utility of couples is strictly higher under a system of joint taxation than under a system of individual taxation generating the same tax revenue.

Proof. Consider an arbitrary type $y$ and proceed in four steps as follows. First, show that joint taxation effectively reduces the consumption risk of couples. Let $c_{i}^{J}$ and $c_{i}^{I}$ respectively denote a couple's state-contingent consumption under joint taxation and individual taxation. As the marginal tax rate is less than $100 \%$, we have $c_{1}>c_{2}$ under both systems. I am going to show that $c_{1}^{J}<c_{1}^{I}$, while $c_{2}^{J}>c_{2}^{I}$, so that consumption is less risky under joint taxation. Under individual taxation, $c_{1}^{I}=2[y-T(y)+s(y)]$, while under joint taxation, $c_{1}^{J}=2[y-T(y)]$. Since $s(y)>0, c_{1}^{J}<c_{1}^{I}$. If one spouse receives no market income, $c_{2}^{I}=y-T(y)+s(y)$ and $c_{2}^{J}=y-2 T(y / 2)$. Thus, one has

$$
c_{2}^{J}>c_{2}^{I} \quad \Leftrightarrow \quad V(y)>s(y) .
$$

By (3), the latter inequality always holds true, so that $c_{2}^{J}>c_{2}^{I}$.

The second step is to determine the rate $r$ at which consumption in state 1 is transformed into state-2 consumption if joint taxation replaces individual taxation. By definition, $r=-\left(c_{2}^{J}-c_{2}^{I}\right) /\left(c_{1}^{J}-c_{1}^{I}\right)$. Inserting the above expressions for state-contingent consumption and making use of (3), the rate of transformation can be computed as

$$
r(\sigma)=\frac{2(1-\pi)+\sigma}{4 \pi} .
$$

The third step consists of showing that if $\sigma=0$, the consumption shift across states implied by a move from individual to joint taxation increases expected utility. Total 
differentiation of (4) yields

$$
-\frac{d c_{2}}{d c_{1}}=\frac{1-\pi}{2 \pi} \frac{U^{\prime}\left(c_{1}\right)}{U^{\prime}\left(c_{2}\right)}
$$

Hence, the slope of indifference curves when consumption is equalized across states is

$$
-\left.\frac{d c_{2}}{d c_{1}}\right|_{c_{1}=c_{2}}=\frac{1-\pi}{2 \pi}
$$

Since the indifference curves are strictly convex and $c_{1}^{J}>c_{2}^{J}$, the slope of the indifference curve at the consumption plan associated with joint taxation has

$$
-\left.\frac{d c_{2}}{d c_{1}}\right|_{c=c^{J}}<\frac{1-\pi}{2 \pi}
$$

If $\sigma=0$, the rate of transformation of state- 1 into state- 2 consumption is, using (5), $r(0)=(1-\pi) / 2 \pi$. By $(6)$,

$$
r(0)>-\left.\frac{d c_{2}}{d c_{1}}\right|_{c=c^{J}}
$$

which implies that the consumption plan associated with individual taxation lies on an indifference curve strictly below the one cutting through $\left(c_{1}^{J}, c_{2}^{J}\right)$. This shows that couples strictly prefer joint taxation if $\sigma=0$.

Finally, it must be shown that also if $\sigma>0$ couples prefer joint taxation over individual taxation. This can be seen from the effect of $\sigma$ on the differential tax $s(y)$. By (3), the consumption level of couples is a strictly decreasing function of $\sigma$ under individual taxation, while it is unaffected by $\sigma$ under joint taxation. Since joint taxation makes couples better off if $\sigma=0$, a fortiori the same is true if $\sigma>0$.

Notice that if $\sigma=0$ there are no singles in the population and a reform from individual to joint taxation generates a strict Pareto improvement.

\subsection{Example with proportional tax adjustment}

The following example exhibits a class of progressive tax schedules for which a Paretoimproving tax reform can be obtained by imposing an additional proportional income tax. That is, a uniform increase of the marginal tax rate is sufficient to make all couples better off when replacing individual taxation with joint taxation with income splitting. Equivalently, the government may keep the same income tax schedule, raise a consumption tax, and adjust welfare payments so that the consumption of the poor is unaffected in real terms.

Proposition 2. Let $T=a[y \ln (b y)-y]$, where $y \in[\underline{y} / 2, \bar{y}], 0<a<1, b \geq 2 e / \underline{y}$. Switching from individual taxation to joint taxation with income splitting and imposing 
an additional tax ty, where

$$
t=\frac{a \pi \ln 4}{2+\sigma},
$$

makes all couples better off.

Proof. It directly follows from computing $V(y)=a y \ln 2$, inserting it into (3), and applying Proposition 1.

\section{Concluding remark}

As compared to individual taxation, joint taxation with income splitting provides couples with more insurance against the risk of earning inability for one of the spouses. Under risk aversion and exogenous incomes, this additional insurance makes couples better off ex ante. This result has been obtained in a model where incentive issues are absent. Under endogenous incomes that additional insurance is bound to generate incentive effects affecting labor supply, home production, and risk-taking. A comprehensive analysis of the welfare effects from the tax treatment of couples should surely take both uncertainty and incentives into account. ${ }^{2}$

\footnotetext{
${ }^{2}$ Chiu and Eeckhoudt (2010) review and extend the analysis of labor supply under risk.
} 


\section{References}

Apps, P. and R. Rees, 2009, Public Economics and the Household, Cambridge University Press: Cambridge.

Chiu, W. H. and L. Eeckhoudt, 2010, The effects of stochastic wages and non-labor income on labor supply: Update and extensions, Journal of Economics 100, 69-83.

Cremer, H., Lozachmeur, J. and P. Pestieau, 2007, Income taxation of couples and the tax unit choice, CESifo WP No. 2005.

Eaton J. and H. Rosen, 1980, Labor supply, uncertainty, and efficient taxation, Journal of Public Economics 14, 365-374.

Fraser, J., 1986, The marriage tax, Management Science 32, 831-40.

Gottfried, P. and W. Richter, 1999, The tax unit and household production: Comment, Journal of Political Economy 107, 404-409.

Kleven, H.J. and C. T., Kreiner, 2007, Optimal taxation of married couples with household production, Finanzarchiv / Public Finance Analysis 63, 498-518.

Kleven, H.J., Kreiner, C.T. and E. Saez, 2009, The optimal income taxation of couples, Econometrica 77, 537-60.

OECD, 2009, Employment Outlook, Paris.

Piggott, J. and J. Whalley, 1996, The tax unit and household production, Journal of Political Economy 104, 398-418.

Schroyen, F., 2003, Redistributive taxation and the household: The case of individual filings, Journal of Public Economics 87, 2527-47.

Varian, H., 1980, Redistributive taxation as social insurance, Journal of Public Economics 14, 49-68. 


\section{Diskussionsbeiträge \\ des Fachbereichs Wirtschaftswissenschaft \\ der Freien Universität Berlin}

2011

2011/1 NEHER, Frank

Markets Wanted - Expectation Overshooting in Transition

Economics

2011/2 KNOLL, Martin / Petra ZLOCZYSTI

The Good Governance Indicators of the Millennium Challenge

Account

Economics

2011/3 KAPPLER, Marcus / Helmut REISEN / Moritz SCHULARICK /

Edouard TURKISCH

The Macroeconomic Effects of Large Exchange Rate Appreciations Economics

2011/4 MÜLLER, Kai-Uwe / Viktor STEINER

Beschäftigungswirkungen von Lohnsubventionen und Mindestlöhnen Economics

2011/5 WRAGE, Markus / Anja TUSCHKE / Rudi K. F. BRESSER

The Influence of Social Capital on CEO Dismissal in Germany

Strategic Management

2011/6 BLAUFUS, Kay / Sebastian EICHFELDER / Jochen

HUNDSDOERFER

The hidden burden of the income tax

FACTS

2011/7 MUCHLINSKI, Elke

Die Rezeption der John Maynard Keynes Manuskripte von 1904 bis 1911

Economics

2011/8 FOSSEN, Frank M.

Personal bankcuptcy law, wealth and entrepreneurship - Theory and evidence from the introduction of a "fresh start"

Economics

2011/9 CALIENDO, Marco / Frank FOSSEN / Alexander KRITIKOS

Personality characteristics and the decision to become and stay

self-employed

Economics 
2011/10 BACH, Stefan / Martin BEZNOSKA / Viktor STEINER A Wealth Tax on the Rich to Bring Down Public Debt? Economics

2011/11 HETSCHKO, Clemens / Andreas KNABE / Ronnie SCHÖB Changing Identity: Retiring from Unemployment Economics

2011/12 BÖRNER, Lars / Battista SEVERGNINI

Epidemic Trade

Economics

2011/13 SIELAFF, Christian

Steuerkomplexität und Arbeitsangebot - Eine experimentelle Analyse FACTS

2011/14 SCHÖB, Ronnie / Marcel THUM

Job Protection Renders Minimum Wages Less Harmful Economics

2011/15 GLOCKER, Daniela / Viktor STEINER

Returns to Education across Europe

Economics

2011/16 CORNEO, Giacomo

A Note on the Taxation of Couples Under Income Uncertainty Economics 